\title{
Synthesis, Structures, and Antimicrobial Activities of Two Cobalt(II) Complexes $\left[\mathrm{Co}\left(\mathrm{L}^{1}\right)_{2}\left(\mathrm{OH}_{2}\right)_{2}\right]$ and $\left[\mathrm{Co}\left(\mathrm{L}^{2}\right)_{2}\right]$
}

\author{
Yong-Jun Han, Li Wang, Qing-Bin Li and Ling-Wei Xue* \\ College of Chemistry and Chemical Engineering, Pingdingshan University, Pingdingshan Henan 467000, P.R. China \\ * Corresponding author: E-mail: pdsuchemistry@163.com
}

Received: 27-10-2016

\begin{abstract}
A new cobalt(II) complex, $\left[\mathrm{Co}\left(\mathrm{L}^{1}\right)_{2}\left(\mathrm{OH}_{2}\right)_{2}\right](\mathbf{1})$, was prepared by the reaction of 3-bromo-5-chlorosalicylaldehyde $\left(\mathrm{HL}^{1}\right)$ with cobalt nitrate in methanol. Reaction of $\mathbf{1}$ with cyclopropylamine in methanol afforded the Schiff base cobalt(II) complex, $\left[\mathrm{Co}\left(\mathrm{L}^{2}\right)_{2}\right](2)$, where $\mathrm{L}^{2}$ is the deprotonated form of 2-bromo-4-chloro-6-(cyclopropyliminomethyl)phenol $\left(\mathrm{HL}^{2}\right)$. The complexes have been characterized by elemental analyses, IR spectroscopy, and single-crystal X-ray diffraction. The $\mathrm{L}^{1}$ ligand coordinates to the $\mathrm{Co}$ atom through the phenolate $\mathrm{O}$ and carbonyl $\mathrm{O}$ atoms, while the $\mathrm{L}^{2}$ ligand coordinates to the $\mathrm{Co}$ atom through the phenolate $\mathrm{O}$ and imino $\mathrm{N}$ atoms. The $\mathrm{Co}$ atom in complex $\mathbf{1}$ adopts octahedral coordination and that in complex $\mathbf{2}$ adopts tetrahedral coordination. The effect of the free ligands and the cobalt complexes on the antimicrobial activities against Staphylococcus aureus, Escherichia coli, and Candida albicans was studied.
\end{abstract}

Keywords: Synthesis; Crystal structure; Antimicrobial; Schiff base; Cobalt complex

\section{Introduction}

Schiff bases are a kind of versatile ligands in coordination chemistry. ${ }^{1-6}$ In recent years, metal complexes of Schiff bases have attracted considerable attention due to their remarkable biological activity, such as antifungal, antibacterial and antitumor property. ${ }^{7-9}$ It has been shown that the Schiff base complexes derived from salicylaldehyde and its derivatives with primary amines, bearing the $\mathrm{N}_{2} \mathrm{O}, \mathrm{N}_{2} \mathrm{~S}, \mathrm{NO}_{2}$ or NSO donor sets, have interesting biological activity. ${ }^{9-12}$ Furthermore, cobalt complexes in its varied oxidation states have become a central theme of current research because of their potentially useful properties in the realm of relevant scientific and technological fields. Recently, we have reported some Schiff base complexes and their application in biological area. ${ }^{13-15}$ In the present work, two new cobalt(II) complexes, $\left[\mathrm{Co}\left(\mathrm{L}^{1}\right)_{2}\left(\mathrm{OH}_{2}\right)_{2}\right](\mathbf{1})$ and $\left[\mathrm{Co}\left(\mathrm{L}^{2}\right)_{2}\right](\mathbf{2})$, where $\mathrm{L}^{1}$ and $\mathrm{L}^{2}$ are the deprotonated forms of 3-bromo-5-chlorosalicylaldehyde $\left(\mathrm{HL}^{1}\right)$ and 2-bromo-4-chloro-6-(cyclopropyliminomethyl)phenol $\left(\mathrm{HL}^{2}\right)$, respectively, are reported.

\section{Experimental}

\section{1. Material and Methods}

3-Bromo-5-chlorosalicylaldehyde, cyclopropylamine, and cobalt nitrate were purchased from Fluka. Other reagents and solvents were analytical grade and used without further purification. Elemental $(\mathrm{C}, \mathrm{H}$ and $\mathrm{N})$ analyses were made on a Perkin-Elmer Model 240B automatic analyzer. Cobalt analysis was carried out by EDTA titration. Infrared (IR) spectra were recorded on an IR-408 Shimadzu 568 spectrophotometer.

\section{2. Preparation of $\left[\mathrm{Co}\left(\mathrm{L}^{1}\right)_{2}\left(\mathrm{OH}_{2}\right)_{2}\right](1)$}

$\mathrm{HL}^{1}(0.23 \mathrm{~g} \mathrm{~g}, 1.0 \mathrm{mmol})$ was dissolved in methanol $(20 \mathrm{~mL})$, then a methanol solution $(10 \mathrm{~mL})$ of $\mathrm{Co}\left(\mathrm{NO}_{3}\right)_{2}$. $6 \mathrm{H}_{2} \mathrm{O}(0.29 \mathrm{~g}, 1.0 \mathrm{mmol})$ was added while stirring. The mixture was stirred for $1 \mathrm{~h}$ at ambient temperature to give a red solution. Red block-shaped single crystals suitable for X-ray diffraction were formed by slow evaporation of the solution in air for about a week. Yield: 45\%. D.p. 173 ${ }^{\circ} \mathrm{C}$. Elemental analysis found: $\mathrm{C}, 29.63 ; \mathrm{H}, 1.92$; $\mathrm{Co}$, 10.67\%. $\mathrm{C}_{14} \mathrm{H}_{10} \mathrm{Br}_{2} \mathrm{Cl}_{2} \mathrm{CoO}_{6}$ calcd: $\mathrm{C}, 29.82 ; \mathrm{H}, 1.79 ; \mathrm{Co}$, $10.45 \%$. IR data (KBr, cm $\left.{ }^{-1}\right): 3433$ (br, m), 1647 (vs), 1505 (m), 1443 (s), 1413 (s), 1313 (w), 1205 (m), 1139 (s), $1080(\mathrm{~s}), 989(\mathrm{~m}), 926(\mathrm{w}), 864(\mathrm{~m}), 747(\mathrm{~s}), 693(\mathrm{w})$, $543(\mathrm{~m}), 409(\mathrm{w})$.

\section{3. Preparation of $\left[\mathrm{Co}\left(\mathrm{L}^{2}\right)_{2}\right](2)$}

To the methanolic solution $(10 \mathrm{~mL})$ of complex $\mathbf{1}$ (56.4 $\mathrm{mg}, 0.100 \mathrm{mmol}$ ) was added a methanolic solution 
(10 mL) of cyclopropylamine ( $11.5 \mathrm{mg}, 0.200 \mathrm{mmol})$. The mixture was stirred for $1 \mathrm{~h}$ at ambient temperature to give a red solution. Red block-shaped single crystals suitable for X-ray diffraction were formed by slow evaporation of the solution in air for three days. Yield: $61 \%$. D.p. $232{ }^{\circ} \mathrm{C}$. Elemental analysis found: C, 39.77; H, 2.58; N, 4.72; Co, $9.9 \%$. $\mathrm{C}_{20} \mathrm{H}_{16} \mathrm{Br}_{2} \mathrm{Cl}_{2} \mathrm{CoN}_{2} \mathrm{O}_{2}$ calcd: $\mathrm{C}, 39.64 ; \mathrm{H}, 2.66 ; \mathrm{N}$, 4.62; Co, 9.7\%. IR data $\left(\mathrm{KBr}, \mathrm{cm}^{-1}\right): 1622(\mathrm{~m}), 1438(\mathrm{~m})$, 1360 (m), 1160 (s), 1072 (s), 951 (s), 860 (s), 543 (m), $518(\mathrm{~m}), 464(\mathrm{w})$.

\section{4. X-ray Diffraction}

Data were collected from selected crystals mounted on glass fibers. The diffraction data were collected on a Bruker SMART $1000 \mathrm{CCD}$ with Mo K $\alpha$ radiation $(\lambda=$ $0.71073 \AA$ ) at $298(2) \mathrm{K}$. The data for the two complexes were processed with SAINT ${ }^{16}$ and corrected for absorption using SADABS. ${ }^{17}$ Semi-empirical absorption corrections were applied with $\psi$-scans. ${ }^{18}$ The structures were solved by direct methods using SHELXS-97, and refined by full-matrix least-squares techniques on $F^{2}$ using anisotropic displacement parameters. ${ }^{19}$ The water hydrogen atoms were located from a difference Fourier map and refined isotropically, with $\mathrm{O}-\mathrm{H}$ and $\mathrm{H} \cdots \mathrm{H}$ distances restrained to $0.85(1)$ and $1.37(2) \AA$, respectively. The remaining hydrogen atoms were placed at the calculated positions. Idealized $\mathrm{H}$ atoms were refined with isotropic displacement parameters set to 1.2 times the equivalent isotropic $U$ values of the parent atoms. The low bond precision on $\mathrm{C}-\mathrm{C}$ bonds of $0.01614 \AA$ for $\mathbf{1}$ was caused by the poor quality of the crystal diffraction. The 18 restraints of $\mathbf{1}$ we- re generated by the $\mathrm{O}-\mathrm{H}$ and $\mathrm{H} \cdots \mathrm{H}$ distances restraints, and the isotropic behavior restraint of $\mathrm{C} 14$. The cyclopropane group C18-C19-C20 of $\mathbf{2}$ was disordered over two sites, with occupancies of $0.352(5)$ and $0.648(5)$, respectively. The crystallographic data for the complexes are listed in Table 1.

\section{Results and Discussion}

\section{1. Chemistry}

A new cobalt(II) complex with $\mathrm{L}^{1}$ as ligand has been prepared. Reaction of this complex with cyclopropylamine afforded a new cobalt(II) complex bearing Schiff base ligand, $\mathrm{L}^{2}$ (Scheme 1). The results of the elemental analyses are in accord with the calculated composition of these complexes. The air-stable cobalt complexes are soluble in DMF, methanol, ethanol, chloroform, and acetonitrile.

\section{2. Infrared Spectra}

The infrared spectrum of complex 1 exhibits strong band at $1647 \mathrm{~cm}^{-1}$, which can be assigned to the $\mathrm{C}=\mathrm{O}$ stretching frequency of $\mathrm{L}^{1}$ ligands. When the carbonyl groups form azomethine groups with cyclopropylamine, the band is absent in the spectrum of complex 2 . Instead, a new band indicative of $\mathrm{C}=\mathrm{N}$ bond is observed at 1622 $\mathrm{cm}^{-1}{ }^{20,21}$ When compared with the spectrum of the free Schiff base $\mathrm{HL}^{2}$, it can be seen that the band is shifted to the lower frequency. This indicates the coordination of the imino $\mathrm{N}$ atom to the cobalt center. The medium and broad

Table 1. Crystal and structure refinement data for $\mathbf{1}$ and $\mathbf{2}$

\begin{tabular}{|c|c|c|}
\hline & 1 & 2 \\
\hline Empirical formula & $\mathrm{C}_{14} \mathrm{H}_{10} \mathrm{Br}_{2} \mathrm{Cl}_{2} \mathrm{CoO}_{6}$ & $\mathrm{C}_{20} \mathrm{H}_{16} \mathrm{Br}_{2} \mathrm{Cl}_{2} \mathrm{CoN}_{2} \mathrm{O}_{2}$ \\
\hline Formula weight & 563.9 & 606.0 \\
\hline Temperature $(\mathrm{K})$ & $298(2)$ & $298(2)$ \\
\hline Crystal system & Monoclinic & Monoclinic \\
\hline Space group & $P 2_{1} / c$ & $P 2_{1} / c$ \\
\hline \multicolumn{3}{|l|}{ Unit cell dimensions } \\
\hline$a(\AA)$ & $7.590(2)$ & $12.319(2)$ \\
\hline$b(\AA)$ & $27.685(2)$ & $22.916(2)$ \\
\hline$c(\AA)$ & $8.639(2)$ & $7.952(1)$ \\
\hline$\beta\left(^{\circ}\right)$ & $101.451(2)$ & $108.83(3)$ \\
\hline$V\left(\AA^{3}\right)$ & $1779.3(5)$ & $2124.6(5)$ \\
\hline$Z$ & 4 & 4 \\
\hline Density $\left(\mathrm{g} \mathrm{cm}^{-3}\right)$ & 2.105 & 1.895 \\
\hline Absorption coefficient $\left(\mathrm{mm}^{-1}\right)$ & 5.784 & 4.841 \\
\hline Reflections collected & 10619 & 8098 \\
\hline Independent reflections & 2778 & 2979 \\
\hline Data/parameters & $1734 / 238$ & $1478 / 290$ \\
\hline Restraints & 18 & 52 \\
\hline Final $R$ indices $[I>2 \sigma(I)]$ & $0.0777,0.1509$ & $0.0355,0.0500$ \\
\hline$R$ indices (all data) & $0.1411,0.1737$ & $0.1024,0.0615$ \\
\hline Goodness-of-fit on $F^{2}$ & 1.054 & 0.913 \\
\hline
\end{tabular}

Han et al.: Synthesis, Structures, and Antimicrobial Activities ... 
<smiles>CC(C)ONC(=O)[OH2+]</smiles>

(1)<smiles>CN1CC1</smiles>

Scheme 1. The synthetic procedure of the complexes

band centered at $3433 \mathrm{~cm}^{-1}$ for the spectrum of complex 1 can be attributed to the $\mathrm{O}-\mathrm{H}$ vibrations of the water ligands. The bands in the region $550-400 \mathrm{~cm}^{-1}$ are assigned to the $\mathrm{Co}-\mathrm{N}$ and $\mathrm{Co}-\mathrm{O}$ vibrations. ${ }^{22}$

\section{3. Crystal Structure Description of the Complex 1}

The molecular structure of the complex $\mathbf{1}$ is shown in Figure 1. The Co atom has an octahedral geometry and coordinated by two deprotonated 3-bromo-5-chlorobenzaldehyde ligands, and two water molecules. The aldehyde ligands act as bidentate ligands and coordinate to the $\mathrm{Co}$ atom through the phenolate $\mathrm{O}$ and carbonyl $\mathrm{O}$ atoms. For the octahedral coordination, the three trans angles are in the range 170.3(3)-177.2(3) ${ }^{\circ}$, and the other angles are in the range $84.9(3)-95.5(3)^{\circ}$, indicating a slightly distorted octahedral geometry (Table 2). The distances of the $\mathrm{Co}-\mathrm{O}$ and $\mathrm{Co}-\mathrm{N}$ bonds are comparable to the values observed in other cobalt(II) complexes with similar coordination. ${ }^{23,24}$ The dihedral angle between the two benzene rings of the ligands is $2.7(3)^{\circ}$. In the crystal structure, the molecules are connected by intermolecular hydrogen bonds $\mathrm{O}-\mathrm{H} \cdots \mathrm{O}$ and $\mathrm{O}-\mathrm{H} \cdots \mathrm{Br}$, forming a 3D network, as
Table 2. Coordinate bond distances $(\AA)$ and angles $\left({ }^{\circ}\right)$ for $\mathbf{1}$ and $\mathbf{2}$

\begin{tabular}{lclr}
\hline $\mathbf{1}$ & & & \\
Co1-O1 & $2.062(7)$ & Co1-O2 & $2.069(6)$ \\
Co1-O3 & $2.087(7)$ & Co1-O4 & $2.062(7)$ \\
Co1-O5 & $2.096(7)$ & Co1-O6 & $2.109(7)$ \\
O4-Co1-O1 & $176.6(3)$ & O4-Co1-O2 & $95.5(3)$ \\
O1-Co1-O2 & $87.1(3)$ & O4-Co1-O3 & $86.7(3)$ \\
O1-Co1-O3 & $90.7(3)$ & O2-Co1-O3 & $177.2(3)$ \\
O4-Co1-O5 & $92.8(3)$ & O1-Co1-O5 & $84.9(3)$ \\
O2-Co1-O5 & $94.4(3)$ & O3-Co1-O5 & $87.3(3)$ \\
O4-Co1-O6 & $94.5(3)$ & O1-Co1-O6 & $87.5(3)$ \\
O2-Co1-O6 & $91.2(3)$ & O3-Co1-O6 & $86.8(3)$ \\
O5-Co1-O6 & $170.3(3)$ & & \\
2 & & & \\
Co1-O1 & $1.904(3)$ & Co1-O2 & $1.890(3)$ \\
Co1-N1 & $1.995(4)$ & Co1-N2 & $1.956(5)$ \\
O2-Co1-O1 & $116.89(14)$ & O2-Co1-N2 & $95.83(16)$ \\
O1-Co1-N2 & $115.96(15)$ & O2-Co1-N1 & $121.64(14)$ \\
O1-Co1-N1 & $95.18(15)$ & N2-Co1-N1 & $112.84(16)$ \\
\hline
\end{tabular}

shown by Figure 2. The corresponding hydrogen bonding parameters are listed in Table 3 . In addition, there are $\pi \cdots \pi$ stacking interactions (Table 4) among the adjacent benzene rings. ${ }^{25}$

Table 3. Hydrogen bonding parameters for $\mathbf{1}$ and $\mathbf{2}$

\begin{tabular}{|c|c|c|c|c|}
\hline$D-\mathrm{H} \cdots A$ & $d(D-\mathbf{H})(\AA)$ & $d(\mathrm{H} \cdots A)(\AA)$ & $\mathrm{d}(D \cdots A)(\AA)$ & $\angle(D-\mathbf{H} \cdots A)\left({ }^{\circ}\right)$ \\
\hline \multicolumn{5}{|l|}{1} \\
\hline O6-H6B $\cdots 4^{\mathrm{a}}$ & $0.85(1)$ & $1.96(5)$ & $2.766(9)$ & $156(11)$ \\
\hline O6-H6A $\cdots \mathrm{Br}^{\mathrm{a}}$ & $0.85(1)$ & $2.72(5)$ & $3.486(7)$ & $151(9)$ \\
\hline $\mathrm{O} 6-\mathrm{H} 6 \mathrm{~A} \cdots \mathrm{O} 2^{\mathrm{a}}$ & $0.85(1)$ & $2.26(9)$ & $2.911(11)$ & $133(11)$ \\
\hline $\mathrm{O} 5-\mathrm{H} 5 \mathrm{~B} \cdots \mathrm{Br} 2^{\mathrm{b}}$ & $0.85(1)$ & $2.78(5)$ & $3.583(7)$ & $158(11)$ \\
\hline $\mathrm{O} 5-\mathrm{H} 5 \mathrm{~B} \cdots \mathrm{O} 4^{\mathrm{b}}$ & $0.85(1)$ & $2.40(10)$ & $3.018(10)$ & $130(11)$ \\
\hline $\mathrm{O} 5-\mathrm{H} 5 \mathrm{~A} \cdots \mathrm{O} 2^{\mathrm{b}}$ & $0.85(1)$ & $1.93(5)$ & $2.729(9)$ & $156(12)$ \\
\hline \multicolumn{5}{|l|}{2} \\
\hline $\mathrm{C} 19-\mathrm{H} 19 \cdots \mathrm{Br} 1^{\mathrm{c}}$ & 0.97 & $2.92(3)$ & $3.660(5)$ & $134(6)$ \\
\hline $\mathrm{C} 17-\mathrm{H} 17 \cdots \mathrm{Br}^{\mathrm{d}}$ & 0.93 & $2.92(3)$ & $3.824(5)$ & $163(6)$ \\
\hline
\end{tabular}

Symmetry codes: (a) $1-x,-y,-z$; (b) $-x,-y,-z$; (c) $x, y, 1+z$; (d) $1-x,-y, 1-z$. 
Table 4. Parameters between the planes for $\mathbf{1}$ and $\mathbf{2}$

\begin{tabular}{|c|c|c|c|c|c|c|}
\hline$C g \cdots C g$ & $\begin{array}{l}C g \cdots C g \\
\text { distance }(\AA)\end{array}$ & $\begin{array}{l}\text { Dihedral } \\
\text { angle }\left(^{\circ}\right)\end{array}$ & $\begin{array}{l}\text { Perpendi cular } \\
\text { distance of } C g(I) \\
\text { on } C g(J)(\AA)\end{array}$ & $\beta\left({ }^{\circ}\right)$ & $\gamma\left({ }^{\circ}\right)$ & $\begin{array}{l}\text { Perpendicular } \\
\text { distance of } C g(J) \\
\text { on } C g(I)(\AA)\end{array}$ \\
\hline \multicolumn{7}{|l|}{1} \\
\hline$C g(1) \cdots C g(2)^{\mathrm{b}}$ & 3.827 & 2.28 & 3.562 & 19.24 & 21.45 & 3.613 \\
\hline$C g(1) \cdots C g(2)^{\mathrm{a}}$ & 3.961 & 2.28 & 3.660 & 21.42 & 22.48 & 3.687 \\
\hline \multicolumn{7}{|c|}{$\begin{array}{l}\mathrm{Cg}(1) \text { and } C g(2) \text { are the centroids of the } \mathrm{C} 1-\mathrm{C} 6 \text { and } \mathrm{C} 8-\mathrm{C} 13 \text { benzene rings, respectively. } \\
2\end{array}$} \\
\hline$C g(3) \cdots C g(3)^{\mathrm{b}}$ & 3.660 & 0.00 & 3.384 & 22.39 & 22.39 & 3.384 \\
\hline \multicolumn{7}{|c|}{$\mathrm{Cg}(3)$ is the centroid of the $\mathrm{C} 1-\mathrm{C} 6$ benzene ring. } \\
\hline
\end{tabular}

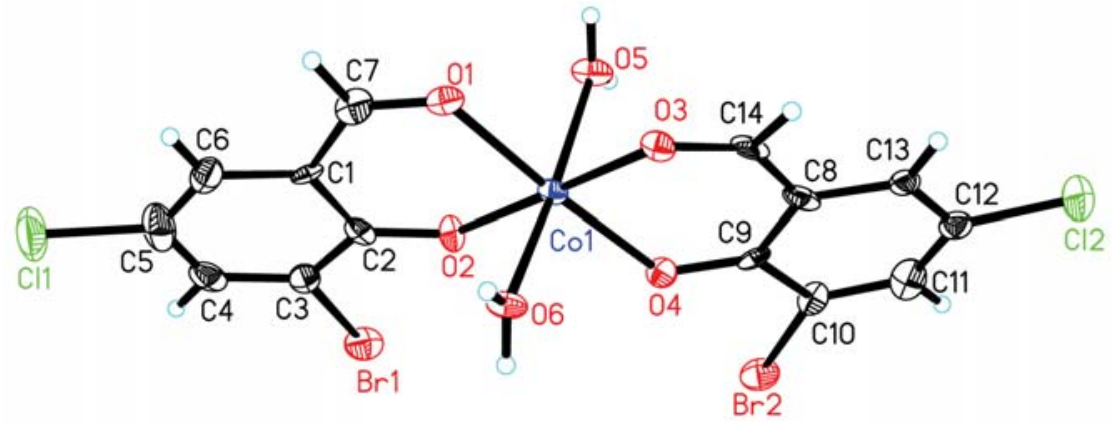

Figure 1. Perspective view of the complex 1 with $30 \%$ probability thermal ellipsoids.

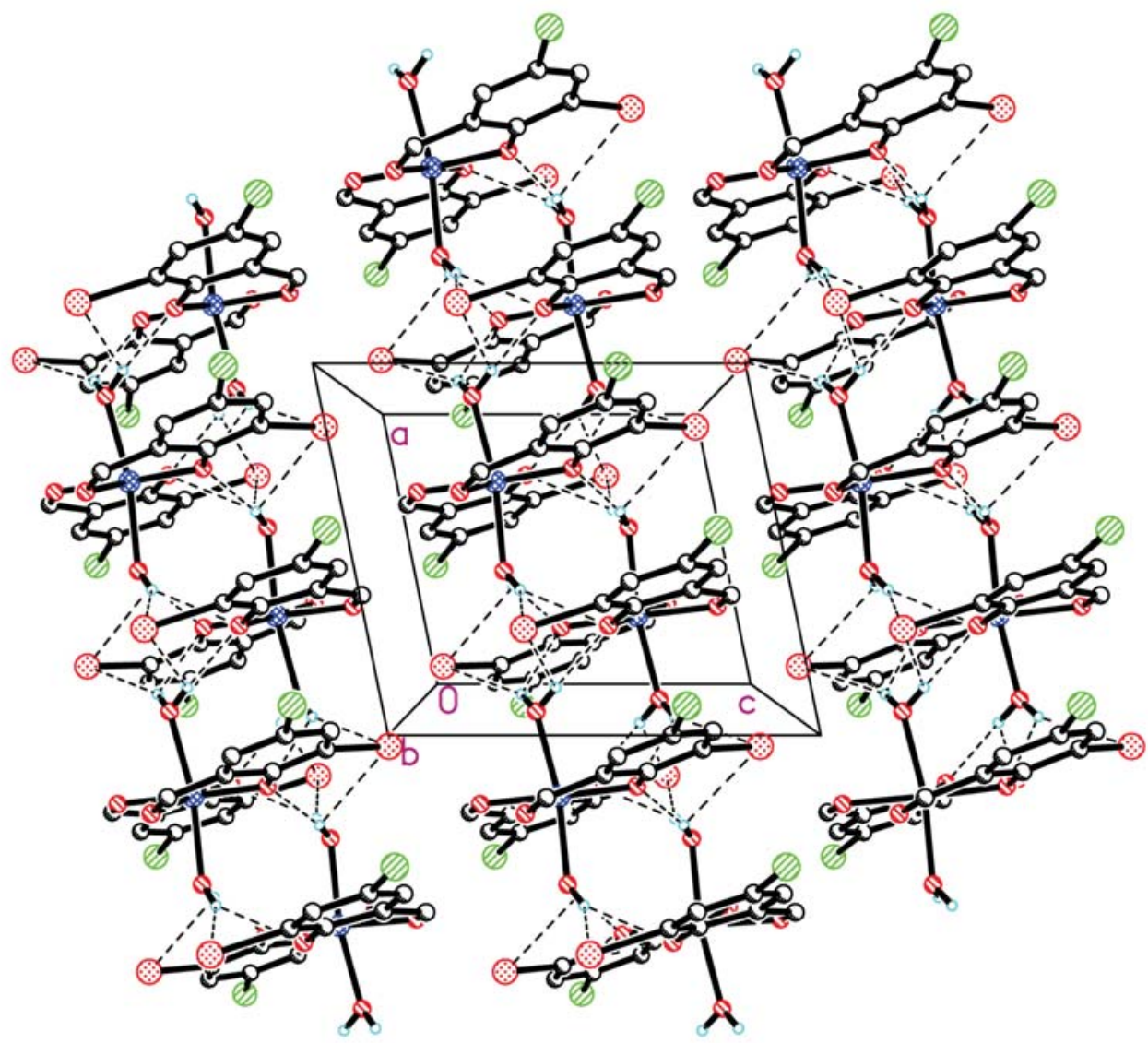

Figure 2. Molecular packing of the complex 1 along the $b$ axis. 


\section{4. Crystal Structure Description of the Complex 2}

The molecular structure of the complex $\mathbf{2}$ is shown in Figure 3. The Co atom has a tetrahedral geometry and is coordinated by two deprotonated Schiff base ligands 2bromo-4-chloro-6-(cyclopropyliminomethyl)phenol. The
Schiff base ligands act as bidentate ligands and coordinate to the Co atom through the phenolate $\mathrm{O}$ and imino $\mathrm{N}$ atoms. For the tetrahedral coordination, the angles are in the range $95.18(15)-121.64(14)^{\circ}$, indicating a slightly distorted tetrahedral geometry (Table 2). The distances of the $\mathrm{Co}-\mathrm{O}$ and $\mathrm{Co}-\mathrm{N}$ bonds are comparable to the values

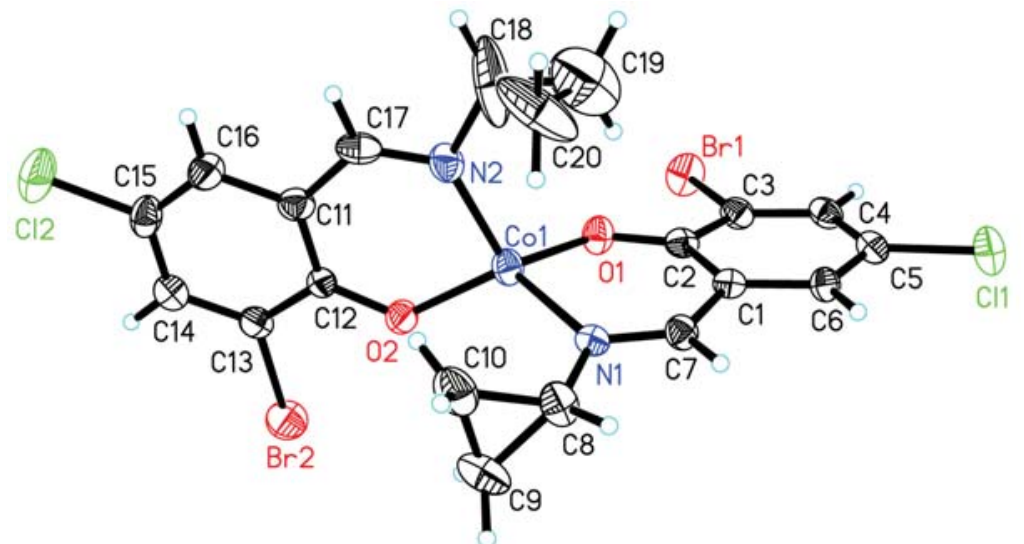

Figure 3. Perspective view of the complex 2 with $30 \%$ probability thermal ellipsoids. Only the major component of the disordered cyclohexane group is shown.

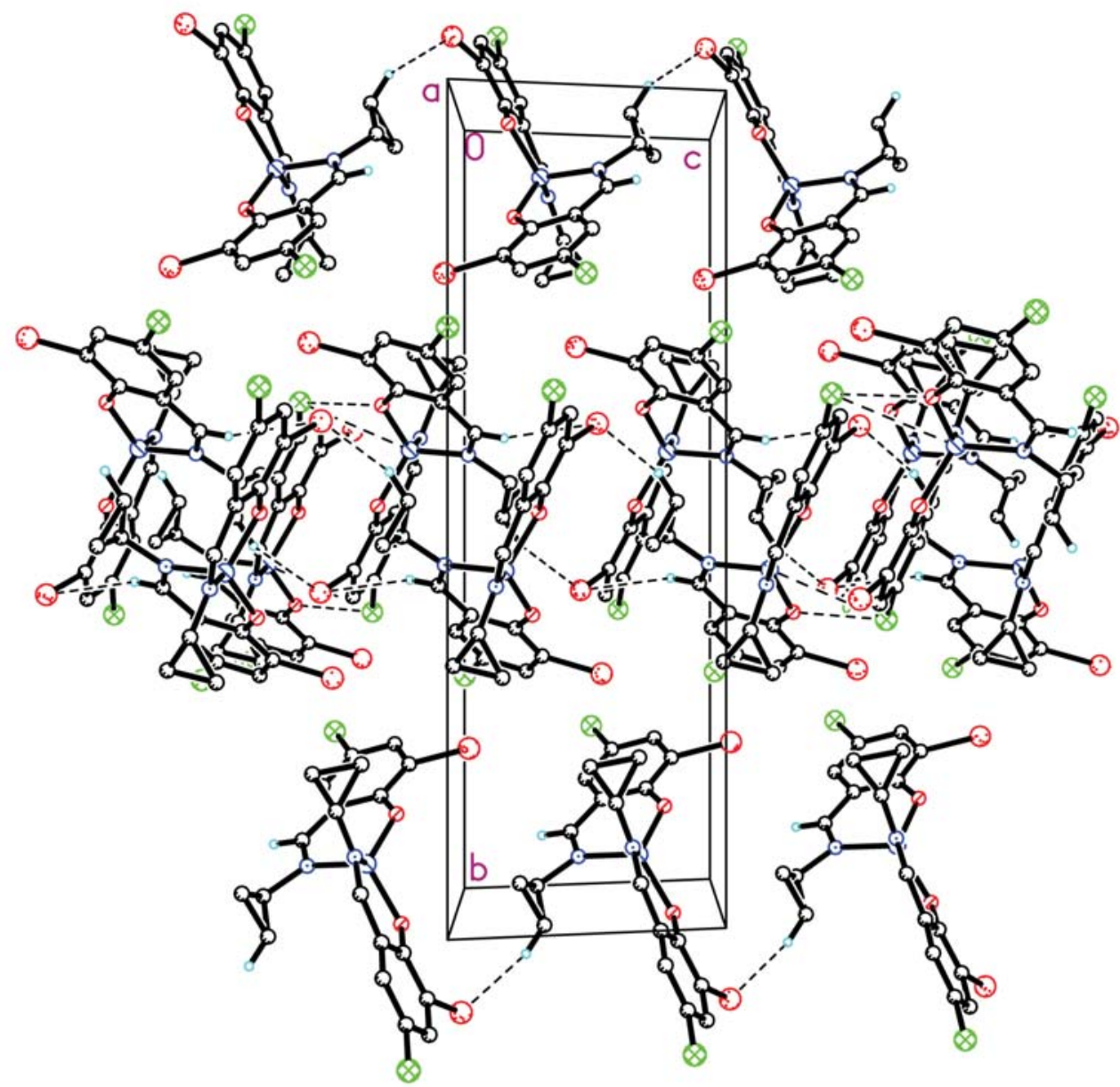

Figure 4. Molecular packing of the complex 2 along the $a$ axis. 
observed in other cobalt(II) complexes with similar coordination. ${ }^{26,27}$ The dihedral angle between the two benzene rings of the ligands is $97.0(3)^{\circ}$. In the crystal structure, the molecules are connected by intermolecular hydrogen bonds $\mathrm{C}-\mathrm{H} \cdots \mathrm{Br}$, forming $2 \mathrm{D}$ layers parallel to the $a c$ plane, as shown by Figure 4 . The corresponding hydrogen bonding parameters are listed in Table 3 . In addition, there are $\pi \cdots \pi$ stacking interactions (Table 4 ) among the adjacent benzene rings. ${ }^{25}$

\section{5. Antimicrobial Activity}

Qualitative determination of antimicrobial activity was done using the disk diffusion method. ${ }^{28,29}$ The results are summarized in Table 4. A comparative study of minimum inhibitory concentration (MIC) values of the free ligands and the complexes indicate that the cobalt complexes have better activity than the free ligands. Generally, this is caused by the greater lipophilic nature of the complexes than the ligands. Such increased activity of the metal chelates can be explained on the basis of chelating theory. ${ }^{30}$ On chelation, the polarity of the metal atoms will be reduced to a greater extent due to the overlap of the ligand orbital and partial sharing of positive charge of the metal atoms with donor atoms. Further, it increases the delocalization of $\pi$-electrons over the whole chelate ring and enhances the lipophilicity of the complexes. This increased lipophilicity enhances the penetration of the complexes into lipid membrane and blocks the metal binding sites on enzymes of microorganisms.

From Table 5, it is obvious that the cobalt complexes show greater antimicrobial and antifungi activities against Staphylococcus aureus, Escherichia coli, and Candida albicans when compared to $\mathrm{HL}^{1}$ and $\mathrm{HL}^{2}$. The complex with Schiff base ligand seems to be more active than that with aldehyde ligand. The activity of complex $\mathbf{2}$ is stronger than 1. For Staphylococcus aureus and Escherichia coli, even though the activities of the cobalt complexes are stronger than those of the free ligands, it is still less than the control drug tetracycline. But for Candida albicans, both complexes show stronger activity than the free ligands and tetracycline. This trend is in accordance with those reported in literature, that cobalt complexes have stronger activities than the free Schiff bases in the antibacterial fields. ${ }^{31,32}$

Table 5. MIC values (ìg/mL) for the antimicrobial activities of the tested compounds

\begin{tabular}{lccc}
\hline & $\begin{array}{c}\text { Staphylococcus } \\
\text { aureus }\end{array}$ & $\begin{array}{c}\text { Escherichia } \\
\text { coli }\end{array}$ & $\begin{array}{c}\text { Candida } \\
\text { albicans }\end{array}$ \\
\hline $\mathrm{HL}^{1}$ & 256 & 128 & $>1024$ \\
$\mathrm{HL}^{2}$ & 64 & 64 & $>1024$ \\
$\mathbf{1}$ & 16 & 8.0 & 256 \\
$\mathbf{2}$ & 1.0 & 4.0 & 128 \\
Tetracycline & 0.32 & 2.12 & $>1024$ \\
\hline
\end{tabular}

\section{Conclusion}

Two new cobalt(II) complexes with 3-bromo-5chlorosalicylaldehyde or 2-bromo-4-chloro-6-(cyclopropyliminomethyl)phenol as ligands have been prepared and characterized. The crystal structures of both complexes were confirmed by X-ray single crystal diffraction. The Co atom in complex $\mathbf{1}$ is in an octahedral coordination, while in complex $\mathbf{2}$, it gives a tetrahedral coordination. The antimicrobial tests show that both complexes have potential activity against Staphylococcus aureus, Escherichia coli and Candida albicans.

\section{Acknowledgements}

This research was supported by the National Sciences Foundation of China (No. 20676057 and 20877036) and Top-class foundation of Pingdingshan University (No. 2008010).

\section{Supplementary Material}

The crystallographic data of the structures described in this paper were deposited with the Cambridge Crystallographic Data Centre as supplementary publication no. CCDC-1489222 (1) and 1489223 (2). Copies of these data are available free of charge from http://www.ccdc.ac.uk/conts/retrieving.html, or from the Cambridge Crystallographic Data Centre, 12 Union Road, Cambridge CB2 1EZ, UK; fax: (+44)1223-336033; or email: deposit @ ccdc.cam.ac.uk.

\section{References}

1. M. He, Q.-Z. Jiao, X.-F. Chen, J. Li, J. Chen, G.-H. Sheng, Z.-L. You, Chinese J. Inorg. Chem. 2016, 31, 1590-1596.

2. D. Qu, F. Niu, X. Zhao, K.-X. Yan, Y.-T. Ye, J. Wang, M. Zhang, Z. You, Bioorg. Med. Chem. 2015, 23, 1944-1949. https://doi.org/10.1016/j.bmc.2015.03.036

3. Y. Zhu, C.-F. Wang, K. Yan, K.-D. Zhao, G.-H. Sheng, Q. Hu, L. Zhang, Z. You, J. Coord. Chem. 2016, 69, 2493-2499. https://doi.org/10.1080/00958972.2016.1186801

4. J. Qin, Q. Yin, S.-S. Zhao, J.-Z. Wang, S.-S. Qian, Acta Chim. Slov. 2016, 63, 55-61. https://doi.org/10.17344/acsi.2015.1918

5. D. Barut, N. Korkmaz, S. T. Astley, M. Aygun, Acta Chim. Slov. 2015, 62, 88-94. https://doi.org/10.17344/acsi.2014.734

6. F.-M. Wang, Acta Chim. Slov. 2016, 63, 406-410. https://doi.org/10.17344/acsi.2016.2520

7. Z.-C. Liu, B.-D. Wang, Z.-Y. Yang, Y. Li, D.-D. Qin, T.-R. Li, Eur. J. Med. Chem. 2009, 44, 4477-4484. https://doi.org/10.1016/j.ejmech.2009.06.009 
8. D.-D. Qin, Z.-Y. Yang, G.-F. Qi, T.-R. Li, Transition Met. Chem. 2009, 34, 499-505.

9. Y.-Y. Yu, H.-D. Xian, J.-F. Liu, G.-L. Zhao, Molecules 2009, 14, 1747-1754. https://doi.org/10.3390/molecules 14051747

10. Z. You, M. Liu, C. Wang, G. Sheng, X. Zhao, D. Qu, F. Niu, RSC Advances 2016, 6, 16679-16690. https://doi.org/10.1039/C6RA00500D

11. Y.-T. Ye, F. Niu, Y. Sun, D. Qu, X.-L. Zhao, J. Wang, D.-M. Xian, H. Jurg, Z.-L. You, Chinese J. Inorg. Chem. 2015, 31, 1019-1026.

12. C. Jing, C. Wang, K. Yan, K. Zhao, G. Sheng, D. Qu, F. Niu, H. Zhu, Z. You, Bioorg. Med. Chem. 2016, 24, 270-276. https://doi.org/10.1016/j.bmc.2015.12.013

13. L. Wang, Y.-J. Han, Q.-B. Li, L.-W. Xue, Acta Chim. Slov. 2016, 63, 822-826. https://doi.org/10.17344/acsi.2016.2699

14. G. P. Cheng, L. W. Xue, C. X. Zhang, Russ. J. Coord. Chem. 2014, 40, 284-288. https://doi.org/10.1134/S1070328414040022

15. L.-W. Xue, Y.-X. Feng, C.-X. Zhang, Synth. React. Inorg. Met.-Org. Nano-Met. Chem. 2014, 44, 1541-1544. https://doi.org/10.1080/15533174.2013.802340

16. Bruker, SMART and SAINT. Area Detector Control and Integration Software, Bruker Analytical X-ray Instruments Inc., Madison, WI, USA, 1997.

17. G. M. Sheldrick, SADABS. Program for Empirical Absorption Correction of Area Detector Data. University of Göttingen, Göttingen, Germany, 1997.

18. A. C. T. North, D. C. Phillips, F. S. Mathews, Acta Crystallogr. 1968, A24, 351-359. https://doi.org/10.1107/S0567739468000707

19. G. M. Sheldrick, SHELXL-97. Program for the Refinement of Crystal Structures, University of Göttingen, Göttingen, Germany, 1997.

20. L. Pan, C. Wang, K. Yan, K. Zhao, G. Sheng, H. Zhu, X.
Zhao, D. Qu, F. Niu, Z. You, J. Inorg. Biochem. 2016, 159, 22-28. https://doi.org/10.1016/j.jinorgbio.2016.02.017

21. F. Niu, K.-X. Yan, L. Pang, D. Qu, X. Zhao, Z. You, Inorg. Chim. Acta 2015, 435, 299-304. https://doi.org/10.1016/j.ica.2015.07.014

22. S. Chandra, U. Kumar, Spectrochim. Acta Part A 2005, 61, 219-224. https://doi.org/10.1016/j.saa.2004.03.036

23. R. L. De, K. Samanta, K. Maiti, E. Keller, Inorg. Chim. Acta 2001, 316, 113-116. https://doi.org/10.1016/S0020-1693(01)00369-3

24. Y. Li, Q. Wu, L. Lecren, R. Clerac, J. Mol. Struct. 2008, 890, 339-345. https://doi.org/10.1016/j.molstruc.2008.05.044

25. A. L. Spek, Acta Crystallogr. 2009, D65, 148-155.

26. Z.-L. You, S.-Y. Niu, Synth. React. Inorg. Met.-Org. NanoMet. Chem. 2007, 37, 29-33. https://doi.org/10.1080/15533170601172393

27. C. Jing, C. Wang, K. Yan, K. Zhao, G. Sheng, D. Qu, F. Niu, H. Zhu, Z. You, Bioorg. Med. Chem. 2016, 24, 270-276. https://doi.org/10.1016/j.bmc.2015.12.013

28. A. Barry, Procedures and theoretical considerations for testing antimicrobial agents in agar media. in: Lorian (Ed.), Antibiotics in Laboratory Medicine, $5^{\text {th }}$ ed. Williams and Wilkins, Baltimore, 1991.

29. T. Rosu, M. Negoiu, S. Pasculescu, E. Pahontu, D. Poirier, A. Gulea, Eur. J. Med. Chem. 2010, 45, 774-781. https://doi.org/10.1016/j.ejmech.2009.10.034

30. J. W. Searl, R. C. Smith, S. Wyard, J. Proc. Phys. Soc. 1961, $78,1174-1176$. https://doi.org/10.1088/0370-1328/78/6/311

31. T. Yang, F. Niu, L. X. Li, Z. N. Xia, Y. Zhang, Z. L. You, Russ. J. Coord. Chem. 2016, 42, 402-409. https://doi.org/10.1134/S1070328416050109

32. X. M. Hu, L. W. Xue, G. Q. Zhao, W. C. Yang, Russ. J. Coord. Chem. 2015, 41, 197-201. https://doi.org/10.1134/S1070328415030045

\section{Povzetek}

Pripravili smo nov kobaltov(II) kompleks, $\left[\mathrm{Co}\left(\mathrm{L}^{1}\right)_{2}\left(\mathrm{OH}_{2}\right)_{2}\right](\mathbf{1})$, z reakcijo 3-bromo-5-klorosalicilaldehida $\left(\mathrm{HL}^{1}\right) \mathrm{s}_{\text {ko- }}$ baltovim nitratom v metanolu. Pri reakciji 1 s ciklopropilaminom v metanolu nastane kobaltov(II) kompleks s Schiffovo bazo, $\left[\mathrm{Co}\left(\mathrm{L}^{2}\right)_{2}\right](2)$, kjer je $\mathrm{L}^{2}$ deprotonirana oblika 2-bromo-4-kloro-6-(ciklopropiliminometil)phenola $\left(\mathrm{HL}^{2}\right)$. Kompleksa sta bila okaratkerizirana z elementno analizo, IR spektroskopijo in monokristalno rentgensko difrakcijo. Ligand $\mathrm{L}^{1}$ se koordinira na $\mathrm{Co}$ atom preko fenolatnega $\mathrm{O}$ atoma in karbonilnega $\mathrm{O}$ atoma, medtem ko se ligand $\mathrm{L}^{2}$ koordinira na $\mathrm{Co}$ atom preko fenolatnega $\mathrm{O}$ atoma in imino $\mathrm{N}$ atoma. Co atom v kompleksu 1 ima oktaedrično koordinacijo, v kompleksu 2 pa tetraedrično koordinacijo. Določena je bila tudi antimikrobna aktivnost prostih ligandov in kobaltovih kompleksov na Staphylococcus aureus, Escherichia coli in Candida albicans. 